his theory necessary to bring it into line with the discovery by Prof. Kamerlingh Onnes that at very low temperatures- $4^{\circ}$ or $5^{\circ}$ absolute-the electrical conductivities of metals become infinite. The external electric field applied to the metal is assisted in bringing the axes of the doublets into line by the field produced by those doublets already in line. The kinetic energy of thermal motion of the doublets tends to destroy the alignment. At ordinary temperatures it is sufficient to destroy the alignment so soon as the external field is withdrawn, and the flow of electrons from doublet to doublet is stopped. But at very low temperatures the energy is not sufficient to modify an alignment once produced, and the flow of electrons continues when the external field is withdrawn. The conductivity in these circumstances will be very high.

From this short account of the present position of the two theories it will be seen that the doublet theory of Sir J. J. Thomson has shown a greater power than the electron theory of co-ordinating the facts of experiment. It has difficulties of its own, both in the nature of its fundamental assumptions and in its power of reproducing the facts quantitatively. It does not appear to provide electrons for emission by incandescent bodies, and in its latest development it involves serious changes not previously suspected in the thermal, thermomagnetic, and thermogalvanic properties of metals at the very low temperatures attained by Prof. Kamerlingh Onnes. But the great flexibility it has shown justifies a more generous treatment of it by those authors and lecturers who have been content to limit their exposition of these questions to the older electron theory.

C. H. LEES

\section{THE STERILISATION OF WATER.}

THE safeguarding of our water supplies is of 1 particular importance at the present time, for there may be considerable risk of pollution if typhoid and cholera cases or "carriers" arrive in any number from the seats of war, as may well be the case. The research work carried out by Dr. Houston is therefore of much value and is summarised in a Report just issued. ${ }^{1}$

Dr. Houston first deals with his "excess lime" method of purification. The hardness of water is chiefly due to bicarbonate of lime (temporary) and sulphate of lime (permanent), the former being kept in solution by the carbonic acid present. In the softening of water lime is added and combines with the free and semi-combined carbonic acid, causing a precipitation of the lime added and of the bicarbonate of lime in the water in the form of the relatively insoluble carbonate of lime. A water treated with the right amount of lime has no caustic alkalinity and has practically no action on the bacteria present. When more than enough lime is added the water is rendered caustically

1 Metropolitan Water Board. Eleventh Report on Research Work, cogether with Index to Research Reports, Nos. i-x inclusive. By Dr. A. C. Houston. Pp. viit52. (London: Metropolitan Water Board, n.d.) Price 2s. $6 d$.

$$
\text { NO. 2390, VOL. 95] }
$$

alkaline and becomes actively bactericidal. Such a water would, however, be unfit for domestic and trade use, but if the excess of lime present be removed by the addition of a sufficiency of water from which the bacteria have been removed, the whole of the mixed water will be softened and purified, and will be satisfactory for all purposes. Dr. Houston has previously shown that if raw river water be stored for from four to five weeks the great majority of the bacteria are removed, and the water is rendered safe for drinking purposes.

The excess lime method of purification consists, then, in the addition of an excess of lime, storage of the alkaline water for a day or thereabouts, so that the bactericidal action may be exerted, addition of a sufficiency of water, purified by storage, to neutralise the excessive alkalinity, and filtration to remove the precipitated carbonate of lime.

Dr. Houston has tested the method on a large scale at Sunbury and at Aberdeen. At Aberdeen Bacillus coli (which may be taken as an index of pollution) was present in the untreated water in from I c.c. to IOo c.c. ; after treatment it was not found in 100 c.c. ; the process is therefore efficient and it is comparatively inexpensive.

Another research which has been carried out by Dr. Houston is an investigation of "water microbes" giving the cholera-red reaction after incubation of cultures for twenty-four hours. The cholera-red reaction (obtained by adding acid to a culture) is a very constant and characteristic reaction of the cholera microbe, and as this organism is frequently conveyed by water, it is important to know whether water organisms other than cholera yield the reaction. It is satisfactory to find that, although eighty microbes out of approximately I 885 sub-cultures gave the cholerared reaction on first being tested, they were easily distinguished from cholera by the application of two or three further simple tests.

Dr. Houston is to be congratulated on the valuable research work he has been able to carry out in the midst of a vast amount of routine work. R. T. Hewlett.

\section{THE LATE PROF. J. COOK WILSON.}

DETH has of late been busy among Oxford residents. The demise of John Cook Wilson, Wykeham Professor of Logic, was not unexpected, for he had been in bad health for more than a year, and indeed had never recovered completely from the shock of his wife's death in January, rgr4. Cook Wilson was a man of quite exceptional attainments. Born at Nottingham and educated at Derby School, he matriculated at Oxford in I868. As scholar of Balliol he took no fewer than four first classes, two being for mathematics and two for classics. These were followed by the Latin Essay, the Conington Prize, and a fellowship at Oriel. After his election as Wykeham Professor he became a fellow of New College, but his affection for Oriel never waned, and his connection with his old college was of late 
years renewed by an honorary fellowship. His lectures and less formal courses of instruction were keenly appreciated, and his influence on the philosophical and logical studies of Oxford was very great. His published works, though giving evidence of much learning and critical acumen, were not copious in relation to the width and depth of his erudition. Cook Wilson was a man of strong views. These he was always ready to maintain with an eagerness and occasional vehemence which amused, but never offended, his interlocutors. His controversy with Archer Hinde over the Timaeus of Plato gave occasion for a display of fighting qualities which is still remembered in Oxford with sympathetic appreciation. $\mathrm{He}$ was not only a finished classical scholar, but also an accomplished mathematician; and to these attainments he added an unusually complete knowledge of German language, literature, and philosophy. One of the subjects to which he had devoted attention was the difficult problem of Greek music. On this he held views which did not coincide with those of many of the recognised authorities, in particular of the late Provost of Oriel, D. B. Monro. It. must be confessed that he had his foibles; among them a somewhat deficient sense of proportion, especially in respect of time. But these in no way interfered with the regard in which he was held for the sterling worth and simplicity of his character. "The Cooker," as he was affectionately styled by his pupils and many of his colleagues, was an enthusiastic volunteer. He did much to keep alive the interest in military matters which in the days before the Boer war showed signs in Oxford, as elsewhere, of a dangerous slackening. $\mathrm{He}$ was practically the creator of the cyclist contingent of the O.U.V., and his manual of training for that body became a model for the cyclist service throughout the army. Many will remember "Das Kochmannslied," a piece of good-natured banter by $\mathrm{H}$. W. Greene, of Magdalen, in which humorous reference was made to Wilson's military prowess, his famous manœuvre for the discomfiture of hostile cavalry, his "gyrotwistive Knasterbart," and his polemic with Archer Hinde. "Multis ille bonis flebilis occidit."

\section{NOTES.}

$W_{\mathrm{E}}$ are officially informed that Prof. H. B. Baker will be unavoidably prevented from attending the Manchester meeting of the British Association, and that, in his place, Prof. W. A. Bone will be the president of the Chemistry Section.

THE following additional information has reached us with reference to the communications which may be expected to be made to Section B of the forthcoming meeting of the British Association :-Prof. P. Henry (Louvain), vinyl acetic nitrite; Dr. A. Hynd, configuration in the sugar group; Dr. Sand, a new cadmium vapour arc lamp; Dr. W. E. S. Turner, ionisation in solvents of low dielectric constant; Dr. Turner and Mr. Cauwood, molecular state of salts in solution; papers on flame and combustion, with experimental illustra- tions, probable contributors, Prof. Dixon, Dr. Wheeler, and Dr. Coward.

A munitions inventions branch of the Ministry has been constituted, with Mr. E. W. Moir as comptroller. The branch, which for the present is located in Armament Buildings, Whitehall Place, will have the duty of considering projects for inventions relating to munitions for warfare on land or matters appertaining thereto. The comptroller and staff of the branch will be assisted in their work of examination, and, if thought necessary, in the investigation and development of any projects that may be considered worthy of being developed, by a panel of honorary scientific and other experts. The following have accepted Mr. Lloyd George's invitation to act on this panel :-Col. Goold Adams, Mr. Horace Darwin, Mr. M. Duckham, Mr. W. Duddell, Dr. S. Z. de Ferranti, Dr. R. T. Glazebrook, Sir R. Hadfield, Dr. J. S. Haldane, Col. N. B. Heffernan, Sir A. Kennedy, Mr. F. W. Lanchester, Dr. A. P. Laurie, Prof. Vivian B. Lewes, Mr. M. Longridge, Mr. W. H. Maw, Sir Hiram Maxim, Capt. Moore, Sir H. Norman, Mr. F. G. Ogilvie, MajorGen. G. K. Scott-Moncrieff, Mr. W. Stokes, Mr. J. Swinburne, Sir J. J. Thomson, Mr. A. J. Walter, Mr. C. J. Wilson. All communications should be addressed to the Comptroller at the address given above.

THE President of the Board of Agriculture and Fisheries has appointed a committee (consisting of Lord Middleton (chairman), Mr. Henry Chaplin, Sir Ailwyn Fellowes, the Hon. Alexander Parker, Major Sir M. Burrell, Bart., Sir G. Greenall, Bart., and Capt. M. S. Adye) to consider and advise the Board as to the steps which should be taken to secure the production and maintenance in England and Wales of a supply of horses suitable and sufficient for military. purposes, especially on mobilisation. Mr. E. B. Wilson, of the Board of Agriculture and Fisheries, has been appointed secretary of the committee.

IT is reported from Stockholm that the Nobel prizes for the present year will amount to $8 \mathrm{Iool}$, , but that the distribution may be postponed. From next year the prizes will be reduced by ri25l., representing the amount of the new Swedish defence tax.

THE sum of I4ol. has.been given to the Royal Society of Arts by Mr. R. Le Neve Foster for the purpose of founding a prize in commemoration of his father, $\mathrm{Mr}$. Peter Le Neve Foster, who was secretary of the society from 1853 to 1879 . The council has decided to offer the prize (consisting of rol. and the society's silver medal) for a paper on "Zinc: its production and industrial applications." Competing papers (which must be typewritten) must reach the secretary of the Royal Society of Arts by, at latest, December 3I, I9I5.

AcCording to a Reuter telegram the Vienna Academy of Sciences has made a grant of $160 l$. to Prof. R. Poech to enable him to conduct anthropological researches among the various races comprisingthe Russian prisoners of war.

We learn from Science that Prof. W. H. Welch, of the Johns Hopkins University, and Dr. S. Flexner, of the Rockefeller Institute for Medical Research, areNO. 2390, VOL. 95] 